\title{
PENINGKATAN KEMAMPUAN MENULIS CERITA PENDEK MELALUI PENDEKATAN KONTEKSTUAL PADA SISWA SMP KELAS VII
}

\author{
Jatuh Padmi \\ Universitas Sanata Dharma \\ E-mail: jatuhpadmi@gmail.com
}

\begin{abstract}
Abstrak
Tujuan penelitian ini adalah meningkatkan kemampuan menulis cerita pendek (cerpen) siswa kelas VII salah satu SMP swasta di Jakarta Tahun Ajaran 2014/2015 melalui pendekatan kontekstual baik proses maupun hasil belajar. Penelitian ini merupakan penelitian tindakan dengan metode penelitian campura (kualitatif dan kuantitatif).Penellitian ini menggunakan model penelitian Kemmis \& Taggart yang terdiri dari 4 tahap, yakni perencanaan, pelaksanaan tindakan, pengamatan, dan refleksi dan dilaksanakan sebanyak 3 siklus.Pengumpulan data diperoleh melalui tes menulis cerpen, observasi,wawancara, jurnaling siswa, dan dokumentasi. Data kualitatf dianalisis dengan cara menggambarkan proses penelitian tindakan dan kualitas kemampuan siswa dalam menulis cerpen melalui pendekatan kontekstual, sedangkan data kualitatif dianalisis menggunakan persentase distribusi normal. Hasil penelitian ini menunjukkan adanya peningkatan kemampuan menulis cerpen melalui pendekatan kontekstual mulai dari pra tindakan, siklus 1, siklus 2 dan siklus 3 dilihat dari nilai rata-rata, kategorisasi, dan skor rata-rata aspek penilaian cerpen.
\end{abstract}

Kata Kunci: pendekatan kontekstual, kemampuan menulis cerpen

\section{Abstract}

The objective of this research was to improve the short story writing ability at grade VII student of one private junior high school in Jakarta of the 2014/2015 Academic Year through contextual approach, both process and outcomes of learning. It was an action research with mix-method research. (qualitative and quantitative). It used Kemmis \& Taggart's action research model which consists of four stages, namely planning, action, observation, and reflection and held in 3 cycles. The data were collected through short stories written tests, observation, interview, student's journaling, and documentation. Qualitatf data was analyzed by describing the process of action research and the quality of student's ability in short stories writing through contextual approach, while qualitative data was analyzed using the percentage of the normal distribution. The results showed an increase in the short stories writing ability through contextual approach ranging from pre-action, cycle 1 , cycle 2 and cycle 3 seen from the average score, categorization, and the average score of short stories aspects of assessment.

Keywords: contextual approach, short story writing ability

\section{PENDAHULUAN}

Tujuan pembelajaran bahasa dan sastra Indonesia adalah mengembangkan kemampuan berbahasa dan apresiasi sastra dalam berkomunikasi baik secara lisan maupun tulisan.Kemampuan berbahasa terdiri dari kemampuan mendengarkan/menyimak, kemampuan berbicara, kemampuan membaca, dan kemampuan menulis. Dalam hal ini, salah satu kemampuan berbahasa yang akan dibahas adalah kemampuan menulis.

Menulis merupakan salah satu kemampuan berbahasa yang bersifat produktif, karena menghasilkan suatu produk, yaitu tulisan.Murray dan Moore (2009:31) serta Daniel Gursky (1993:17) sepakat bahwa menulis adalah suatu proses yang kompleks dan kreatif. Seseorang perlu belajar merangkai kata atau kelompok kata, memilih kata yang sesuai dengan konteks kemudian merangkaikannya dalam kalimat dan paragraf dengan bahasa yang mudah dipahami oleh pembaca. Dengan kreativitasnya, penulis mempengaruhi emosi pembacanya agar larut dalam kisah yang ditulisnya (Andrias Harefa, 2007:77).Senada dengan hal tersebut Amstrong dalam Aksan (2011:15) memaparkan bahwa menulis dapat meningkatkan kecerdasan linguistik seseorang. Seseorang yang memiliki inteligensi lingusitik akan mampu menggunakan dan mengolah kata-kata secara efektif baik secara lisan maupun tertulis.

Untuk menjadi terampil menulis, seseorang perlu berlatih secara intensif.Kesabaran dan kegigihan adalah faktor utama seseorang belajar menulis. Ideris (2013:424) menjelaskan bahwa agar menulis menjadi kegiatan yang mudah dan menyenangkan, seseorang harus mempunyai pola pikir, yakni (1) berani bermimpi dan kerja keras, (2) tidak bergantung fasilitas hebat, (3) tidak tergantung bakat, usia, dan jenjang pendidikan, (4) memerlukan motivasi, (5) pandai mengatur waktu dan melawan diri, dan (6) memposisikan diri sebagai pembelajar.

Agar latihan menulis berjalan efektif, MaCrimmon (1984:10-11) menjelaskan tahap-tahap menulis, yakni 
perencanaan, pembuatan draf dan pengembangannya, serta revisi. Philbin dan Persley (1989:128-153) menambahkan adanya tahap penulisan setelah revisi, yakni editing dan review. Richards dan Renandya (2002:316-319) melengkapi dengan menambahkan tiga tahap eksternal dalam proses menulis sebagai aktivitas kelas yang dilakukan oleh guru, yakni responding (sharing), evaluating, dan post-writing. Dari pernyataan di atas dapat disimpulkan bahwa tahap-tahap menulis terdiri dari perencanaan (pre writing), pembuatan draf, responding, revisi, editing, rewiew, evaluasi, dan post writing.

Cerpen merupakan salah satu bentuk karya sastra. Zainurrahman (2011:37) dan Joyce, serta Feez, dan Gibbons (2010:167) memiliki pemahaman yang sama tentang cerpen, yakni sebuah teks narasi yang bersifat fiksi dan menceritakan kejadian dan permasalahan (konflik).Teks naratif tersebut digunakan dalam Kegiatan Belajar dan Mengajar (KBM) dengan tujuan menghibur dan sarana peneneman nilai-nilai sosial dan moral Edgar Allan Poe dalam Abrams (1999:286-287) dan J. Berg Esenwein dalam Colibaba (Synergy volume 6, no. 2/2010h) menambahkan bahwa cerpen memiliki sifat "pendek", yakni selesai dibaca dalam sekali duduk, kirakira berkisar antara setengah jam sampai dua jam dan dibatasi oleh kekhasan tertentu dan memiliki efek tunggal. Dari penjelasan beberapa ahli di atas dapat disimpulkan bahwa cerpen adalah teks naratif pendek fiktif dengan alur tunggal sederhana yang menceritakan sebuah kejadian dengan tujuan menghibur atau menanamkan nilai moral.

Nurgiyantoro (2013:116), Keraf (2006:113), Elizabeth McMahan, Susan Day, \& Robert Funk (1995:122), Janet Burroway, Elizabeth Stuckey-French, \& Ned Stuckey-French (2011:14), Garry Disher (2011:44), dan Margaret Lucke (1999:4-5) sepakat bahwa sebuah cerpen yang baik biasanya harus memiliki unsur pembangun, yakni tema, alur/plot, perwatakan, latar/setting, sudut pandang (point of view), dan gaya penulisan. Tema adalah ide sebuah cerita yang bersifat mengikat, menjiwai, implisit, dan merasuki seluruh cerita, dan isinya mengangkat masalah kehidupan.Alur/plot adalah peristiwa-peristiwa cerita yang mempunyai penekanan pada adanya hubungan kausalitas. Perwatakan (karakterisasi) adalah cara penulis melukiskan tokoh-tokoh dalam cerita yang ditulis. Latar atau setting adalah tempat, waktu, dan lingkungan sosial yang ada di dakam cerita.Sudut pandang (point of view)adalah teknik, siasat atau strategi yang secara sengaja dipilih pengarang untuk mengungkapkan gagasan dan ceritanya.Gaya penulisan merupakan bagian dari pilihan kata yang mempersoalkan cocok atau tidaknya pemakaian kata, frase, atau klausa tertentu untuk menghadapi situasi tertentu.Gaya penulisn cerpen adalah mudah, sederhana, dan ringkas.

Dari pejelasan di atas dapat disimpulkan bahwa kemampuan menulis cerpen adalah suatu kesanggupan untuk mengungkapkan ide, perasaan atau pikiran melalui bentuk tulisan prosa narasi pendek fiksi yang dengan tujuan menghibur dan penyampaian pesan moral.Dalam penulisan cerpen perlu diperhaitkan tahapan menulis, yaitu perencanaan (pre writing), pembuatan draf, responding, revisi, editing, rewiew, evaluasi, dan post writing.Selain itu, juga perlu dipahami unsur-unsur pembangun cerpen, yakni tema, alur atau plot, setting/latar, perwatakan, sudut pandang, dan gaya penulisan.

Siswa dapat belajar banyak dari materi menulis cerpen. Siswa dapat mengembangkan minatnya terhadap apresiasi sastra dengan cara berlatih menulis cerpen.Para siswa dapat menuliskan pengalaman-pengalaman hdupanya yang menarik dan membagikannya kepada orang lain dalam bentuk cerpen yang imajinatif. Bahkan, cerpen yang ditulis mampu menginspirasi pembaca.Sebaliknya, dengan membaca cerpen, para siswa juga belajar dari pengalaman orang lain yang dikisahkan melalui cerpen tersebut.

Guru juga dapat menginternalisasikan nilai-nilai kehidupan melalui media cerpen tanpa terkesan menggurui.Para siswa secara kritis diharapkan mampu menemukan makna kehidupan dibalik tulisan cerpen.Singkatnya, guru pun dapat mendidik siswa melalui tulisan cerpen yang disajikan.

Sekarang ini, pembelajaran menulis cerpen di sekolah lebih banyak pada teori daripada mengakrabkan siswa dengan karya sastra secara langsung.Karena sifat pembelajarannya yang teoretis, para siswa mengalami kesulitan dalam menuliskan ide cerita pendek dengan baik, benar, dan sistematis.Pada pembelajaran menulis cerpen, siswa diajak untuk berpikir kritis, kreatif, dan sistematis.Akan tetapi, kenyataan tersebut sekarang ini sulit untuk direalisasikan di kelas, terutama pada saat KBM.Hal tersebut disebabkan oleh pendekatan pembelajaran yang digunakan selama ini adalah teacher centered dengan metode belajar ceramah. Pembelajaran yang bersifat satu arah tersebut menyebabkan siswa cepat bosan dan kurang kreatif.Akibatnya, pembelajaran menulis cerita pendek dirasa kurang menarik.

Pada pembelajaran menulis cerpen, guru memberikan tema khusus.Pada saat memilih tema menulis cerpen, siswa seolah-olah menjadi dibatasi oleh pemikiran guru.Hal tersebut menyebabkan siswa menjadi kesulitan menuangkan ide dalam pikirannya ke dalam tulisan cerpen.

Guru juga kurang memperhatikan kebutuhan siswa atau konteks awal siswa dalam pembelajaran menulis cerpen.Penilaian tulisan siswa hanya dilihat dari hasil akhir tulisan saja. Guru kurang memberikan apresiasi terhadap segala kreativitas dari siswa yang berasal dari pengalamannya dan bagaimana cara siswa menuangkan ide atau gagasannya menjadi sebuah cerita yang menarik berdasarkan kemampuannya masing-masing.

Ketidaknyamanan siswa dalam belajar karena beberapa penjelasan yang telah dijelaskan di atas menyebabkan hasil belajar siswa kurang memuaskan.Berdasarkan hasil tes pembelajaran menulis cerpen siswa kelas VII SMP Kolese Kanisius, Tahun Ajaran 2014-2015 dapat diketahui bahwa kemampuan menulis cerpen siswa masih kurang.Hal tersebut ditunjukkan dengannilai rata-rata kemampuan menulis cerpen siswa sebelum mendapatkan tindakan pembelajaran dengan pendekatan kontekstual sebesar 3,0 
(60). Rata-rata nilai tersebut berada di bawah nilai KKM bidang studi Bahasa Indonesia di SMP Kolese Kanisius Jakarta, yakni 70 . Dari 42 orang siswa, hanya $3(7,14 \%)$ orang siswa yang memenuhi nilai KKM dan dinyatakan lulus, sedangkan $39(92,86 \%)$ orang siswa memiliki nilai di bawah standar KKM dan dinyatakan tidak lulus. Nilai tertinggi yang diperoleh adalah 3,85 (77) dan nilai terendah yang diperoleh adalah 2,4 (48).

Melihat kenyataan tersebut, perlu dipikirkan pemecahan masalah agar pembelajaran menulis cerpen siswa kelas VII SMP Kolese Kanisius dapat berjalan dengan optimal dan memiliki kualitas hasil tulisan cerpen yang memuaskan.Penerapan pendekatan kontekstual diharapkan dapat diterapkan oleh guru dalam pembelajaran menulis cerita pendek.Pendekatan kontekstual adalah pendekatan yang menitikberatkan pada kebermaknaan belajar.Dengan demikian, target pembelajaran dapat tercapai, yakni guru mampu memberdayakan potensi siswa secara alami sehingga siswa terlatih untuk menulis cerpen berdasarkan pengalamannya dan memasukkan unsur nilai-nilai kehidupan di dalam tulisan cerpennya.Berdasarkan latar belakang dan permasalahan yang dihadapi tersebut, tujuan penelitian ini adalah untuk menjelaskansecara mendalam proses pembelajarandan hasil peningkatan kemampuan menulis cerpen melalui pendekatan kontekstual pada siswa kelas VII SMP Kolose Kanisius Jakarta Tahun Ajaran 2014-2015 dalam Bidang Studi Bahasa Indonesia.

Pendekatan dalam pembelajaran adalah dasar teoritis dalam merencanakan, melaksanakan suatu pembelajaran yang akan dijadikan pedoman dalam pemilihan metode, teknik dalam mengajar dan nantinya akan diterapkan dalam pelaksanaan kegiatan belajar mengajar dalam rangka mencapai tujuan pembelajaran secara optimal.Pada penelitian ini, pendekatan yang digunakan adalah pendekatan kontekstual (Contextual Teaching and Learning).Sanjaya (2006:125) dan Jhonson (2010: 67) mengemukakan hal yang sama bahwa Contextual Teaching Learning (CTL)menekankan kepada proses keterlibatan siswa secara penuh untuk dapat menemukan materi yang dipelajari dan menghubungkannya dengan situasi kehidupan nyata sehingga mendorong siswa untuk dapat menerapkannya dalam kehidupan mereka.Materi pelajaran dalam pendekatan CTL diharapkan dapat menjadi bekal siswa dalam kehidupan nyata.

Pada dasarnya pembelajaran melalui pendekatan kontekstual menekankan pada pembelajaran berbasis masalah.Selain itu, guru perlu memahami konteks belajar siswa baik pengetahuan maupun latar belakang sosial budayanya.Materi pembelajarannya pun bersifat kontekstual, artinya menyentuh nilai-nlai kehidupan nyata.Hal tersebut akan pada kemampuannya untuk belajar mandiri baik secara pribadi maupun kelompok.

Yamin (2013:56) menjelaskan komponen CTL, yakni konstruktivisme, inkuiri, bertanya, masyarakat belajar, modeling, refleksi, pemilaian autentik.Pada dasarnya dalam CTL siswa mengaktifkan pengetahuan yang sudah ada, siswa memperoleh pengetahuan yang baru berdasarkan pengalamanya, memahami, menerapkannya, dan merefleksikannya. Guru berfungsi hanya sebagai fasilitator saja. Dari penjelasan di atas dapat disimpulkan bahwa CTL: (1) menerapkan metode pembelajaran student centered,(2) materi belajar bersifat kontekstual(3) hasil pembelajaran diimplementasikan dalam kehidupan nyata.

\section{METODE}

Metode penelitian ini adalah penelitian tindakan model Kemmis \& Taggart. Rancangan penelitian tindakan model Kemmis \& Taggart mencakup tahap perencanaan (plan), pelaksanaan (act), pengamatan (observe), dan refleksi (reflect) (Stringer, 2007:19-20). Model ini digambarkan dalam bentuk spiral, artinya penelitian dilakukan secara berulang-ulang, sampai tujuan penelitian tercapai.

Penelitian tindakan model Kemmis \& Taggart menekankan pada proses inkuiri (Hopkin's, 2001993:48). Oleh karena itu, pada tahap perencanaan perlu dipikirkan cara untuk merangsang inkuiri siswa. Pada tahap pelaksanaan, para siswa dirangsang untuk aktif bertanya. Melalui teknik bertanya siswa diusahakan mampu menggali jawaban atas pertanyaannya sendiri. Pada tahap pengamatan, observer mengamati dan menuliskan kejadian atau peristiwa pada waktu kegiatan pembelajaran berlangsung, pertanyaan yang disampaikan oleh siswa, dan kesan pembelajaran dalam buku harian. Pada tahap refleksi, guru perlu merenungkan kembali mengenai cara mengajar yang terarah pada tujuan yang ingin dicapai dengan segala permasalahan yang dihadapi.

Subyek penelitian ini adalah siswa kelas VII-5 dan VII-6 salah satu SMP swasta di Jakarta, Tahun Ajaran 2014-2015 sebanyak 42 siswa. Data pada penelitian ini dibagi menjadi dua, yakni data data kualitatif dan kualitatif.Data kualitatif adalah data yang berbentuk katakata yang diperoleh dari hasil penulisan jurnaling siswa, hasil wawancara, hasil observasi yang dilakukan peneliti atau kolaborator yang lain, dan hasil dokumentasi.

Pengumpulan data kuantitatif dilakukan dengan mengadakan tes tertulis,yakni tes menulis cerpen. Data kualitatif dianalisis untuk menggambarkan proses penelitian tindakan yang dilakukan dan kualitas kemampuan siswa dalam menulis cerpen melalui pendekatan kontekstual. Pengumpulan data kualitatif dilakukan dengan melakukan observasi, wawancara, penulisan jurnaling siswa, dan pengumpulan dokumentasi.Teknik pengolahan data kuantitatif dianalisis menggunakan inter-rater dan prosentase distribusi normal.

\section{HASIL DAN PEMBAHASAN}

Hasil tindakan pembelajaran menulis cerpen melalui pendekatan kontekstual pada siswa kelas VII salah satu SMP swasta di Jakarta Tahun Ajaran 2014/2015 terdiri dari tiga deskripsi hasil: (1) deskripsi peningkatan kemampuan menulis cerpen siswa per siswa (2) deskripsi peningkatan kemampuan menulis cerpen siswa berdasarkan kategorisasi, dan (3) deskripsi analisis peningkatan skor rata-rata aspek-aspek penilaian cerpen. Hasil tindakan pembelajaran menulis cerpen melalui pendekatan kontekstual pada siswa kelas VII salah satu 
SMP swasta di Jakarta Tahun Ajaran 2014-2015 dapat dicermati pada grafik dan diagram berikut ini.

Siklus 1dilaksanakan sebanyak 3 (tiga) kali pertemuan. Pada siklus ini, peneliti telah melaksanakan rancangan pembelajaran dengan menerapkan pendekatan kontekstual dalam kegiatan menulis cerpen.Materi yang diberikan adalah struktur cerpen, bahasa cerpen, perbedaan teks cerpen dengan teks lain, dan langkahlangkah menyusun teks cerpen.

Selama pembelajaran siklus I dilakukan pengamatan oleh peneliti dan mitra kolaborasi. Subjek pengamatan adalah guru dan siswa yang mendapat tindakan. Objek observasi meliputi: cara guru mengajar dan aktivitas belajar siswa.Pada tahap pengamatan ini, peneliti berperan sebagai guru sedangkan kolaborator berperan sebagai pengamat. Peneliti dan kolaborator juga bekerja sama untuk mengamati siswa.

Dari hasil pengamatan dan refleksi pada siklus 1, diketahui bahwa siswa belum memahami pentingnya menulis cerpen. Siswa kurang serius mengikuti pembelajaran menuis cerpen. Siswa kurang proaktif dan kurang memiliki inisiatif dalam menanggapi penjelasan dan pertanyaan dari guru maupun teman sekelas. Oleh karena itu, guru perlu memberikan apersepsi secara konkrit, memberikan motivasi lebih lagi (misalnya melalui games, punish \& reward), dan memberikan pendalaman konsep materi, sedangkan siswa perlu berdiskusi lebih serius dan mengikuti pembelajaran secara aktif dan disiplin mengerjakan tugas.

Peneliti menyadari bahwa masih ada beberapa hal yang perlu diperbaiki. Oleh karena itu, hasil refleksi peneliti digunakan sebagai bahan pertimbangan dalam merencanakan tindakan pada siklus 2 agar proses pembelajaran dapat berlangsung lebih maksimal dengan hasil belajar yang lebih optimal.

Berdasarkan nilai akhir pada tindakan siklus 1, ratarata nilai kemampuan menulis cerpen siswa adalah sebesar 3,5 (70). Dari 42 siswa, 18 siswa (42,86\%) memiliki nilai di bawah standar KKM dan dinyatakan tidak lulus. Siswa yang dinyatakan lulus ada sebanyak 24 siswa ( $57,14 \%)$. Nilai tertinggi yang diperoleh adalah 4,15 (83) dan nilai terendah yang diperoleh adalah 2,8 (56). Terdapat 3 siswa yang mengalami penurunan nilai rata-rata, yakni BI $(3,45$ menjadi 3,25$)$, SB (3,30 menjadi $3,20)$, dan GN (3,55 menjadi 3,45). Selain itu, ada seorang siswa yang tidak mengalami perubahan (tetap), yakni AN $(3,40)$.

Setelah tindakan pembelajaran siklus 1 terdapat 5 siswa $(11,9 \%)$ yang memiliki kemampuan menulis cerita pendek kategori "sangat tinggi", 20 siswa $(47,6 \%)$ memiliki kemampuan menulis cerita pendek kategori "tinggi", 17 siswa (40,5\%) yang memiliki kemampuan menulis cerita pendek kategori "sedang". Jadi, secara umum kemampuan menulis siswa kelas VII salah satu SMP swasta di Jakarta berada pada kategori "tinggi".

Dilihat dari segi analisis aspek penilaian, setelah tindakan pembelajaran siklus 1 , nilai rata-rata aspek kelengkapan formal cerpen sebesar 3,9 (78). Aspek kelengkapan unsur intrinsik memiliki nilai rata-rata sebesar 3,2 (64). Aspek komposisi/struktur cerpen memiliki nilai rata-rata sebesar 3,6 (72). Aspek bahasa cerpen memiliki nilai rata-rata sebesar 4,1 (82). Gambaran aspek penilaian di atas memberikan informasi bahwa aspek bahasa cerpen memiliki nilai rata-rata tertinggi dan aspek kelengkapan unsur intrinsik memiliki nilai rata-rata terendah. Dengan demikian dapat dikatakan bahwa siswa memiliki pemahaman yang semakin mendalam pada aspek bahasa cerpen, komposisi/struktur cerpen.Siswa masih memiliki pemahaman yang kurang mengenai aspek kelengkapan unsur intrinsik cerpen.

Indikator keberhasilan tindakan pembelajaran menulis cerpen melalui pendekatan kontekstul pada siklus 1 adalah (1) sebesar $20 \%$ (8 orang) dinyatakan lulus atau nilainya di atas nilai KKM (70), (2) rata-rata nilai meningkat menjadi 3,2,(3) kemampuan siswa dalam menulis cepen minimal berada pada kategori "sedang".

Jika hasil pembelajaran menulis cerpen seperti telah dijelaskan di atas dibandingkan dengan kriteria keberhasilan tindakan, dapat diketahui bahwa (1) indikator keberhasilan pertama tidak terpenuhi karena dari hasil penelitian siklus 1 masih ada 18 siswa $(42,86 \%)$ belum lulus atau nilainya di bawah nilai KKM, (2) rata-rata nilai yang didapat melampaui target keberhasilan yang diharapkan,yakni 3,5 (70),(3) kategorisasi kemampuan menulis cerpen sesuai dengan dari target keberhasilan yang diharapkan, yaitu "tinggi". Karena belum semua kriteria keberhasilan tercapai, peneliti memutuskan untuk melanjutkan ke siklus selanjutnya, yakni siklus 2 dengan melakukan pendalaman materi unsur intrinsik cerpen.

Pelaksanaan siklus 2 difokuskan pada permasalahan atau kekurangan yang ada berdasarkan hasil refleksi pada pelaksanaan siklus 1 . Pelaksanaan siklus 2 terdiri dari 3 kali pertemuan. Fokus materi yang diajarkan adalah klasifikasi teks cerpen, telaah isi teks cerpen, cara merevisi isi dan bahasa teks cerpen dan langkah-langkah meringkas teks cerpen.

Pada tahap pengamatan siklus 2 ini, peneliti berperan sebagai guru sedangkan kolaborator berperan sebagai pengamat. Peneliti dan kolaborator juga bekerja sama untuk mengamati siswa. Dari hasil pengamatan dan refleksi yang dilakukan dapat diketahui bahwa perlu adanya penegasan ulang kembali waktu penulisan cerpen dan pendalaman mengenai konsep materi unsur intrinsik dikarenakan ada beberapa siswa yang termasuk ke dalam tipe pembelajar yang "lamban" yang belum memahami konsep dan belum menyelesaikan menulis cerpen. Oleh karena itu, digunakan strategi pembelajaran menggunakan mind mapping. Atas dasar proses yang belum tuntas tersebut, peneliti melanjutkan tindakan pada siklus ke 3.

Dilihat dari segi kuantitas, setelah tindakan pembelajaran siklus 2, diketahuinilai rata-rata yang diperoleh adalah 3,9 (78). Ada sebanyak 41 siswa $(97,6 \%)$ yang nilainya melampaui KKM dan dinyatakan lulus. Siswa yang nilainya berada di bawah KKM hanyaada 1 siswa $(2,4 \%)$ dan dinyatakan tidak lulus. Nilai tertinggi yang diperoleh adalah 4,3 (86) dan nilai terendah yang diperoleh adalah 3,1 (62). 


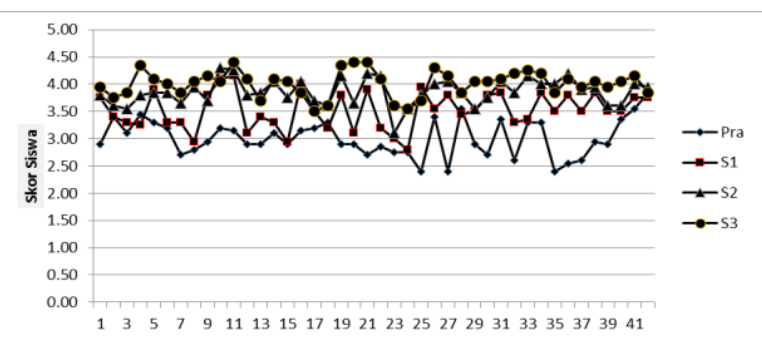

Grafik 1.Tingkat Kemampuan Menulis Cerpen Siswa Kelas VII SMP Kolese Kanisius Tahun Ajaran 20142015 Pra Tindakan, Siklus 1, Siklus 2, dan Siklus 3

Berdasarkan grafik di atas, Jika dibandingkan dengan hasil tindakan pembelajaran siklus 1 , hasil tindakan pembelajaran siklus 2 mengalami peningkatan sebesar $40,48 \%$. Walaupun demikian, ada 4 siswa yang mengalami penurunan nilai pada siklus 2 ini.Empatsiswa tersebut adalah siswa yang berbeda dengan siswa yang mengalami hal yang sama pada siklus 1 , yakni CHR, DE, EMN, dan IGA.

Setelah tindakan pembelajaran siklus 2, diketahui sebanyak 11 siswa $(26,2 \%)$ memiliki kemampuan menulis cerpen kategori "sangat tinggi", 27 siswa $(64,3 \%)$ memiliki kemampuan menulis cerpen dalam kategori "tinggi", dan sisanya, sebanyak 4 siswa $(9,5 \%)$ termasuk dalam kategori "sedang". Jadi secara umum, kemampuan menulis cerpen siswa berada dalam kategori “tinggi”.Secara kategori kemampuan menulis cerpen siswa tidak mengalami perubahan.

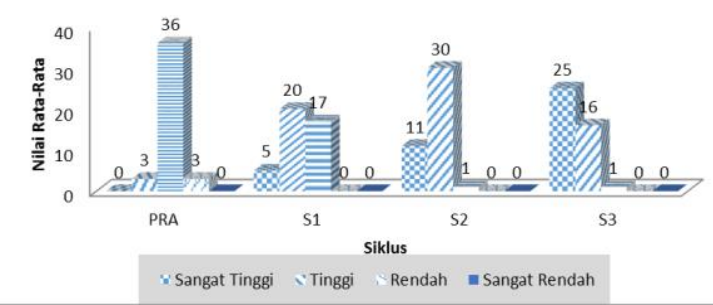

Diagram 1.Tingkat Kemampuan Menulis Cerita Pendek Siswa Kelas VII salah satu SMP swasta di Jakarta Tahun Ajaran 2014-2015 Pra Tindakan, Siklus 1, Siklus 2, dan Siklus 3

Berdasarkan diagram di atas, baik pada siklus 1 maupun siklus 2 kategori kemampuan menulis cerpen siswa tetap berada pada kategori "tinggi". Akan tetapi jika dilihat dari jumlah siswa yang termasuk dalam kategori "tinggi", ada peningkatan jumlah siswa pada siklus 2 ini, yakni dari 20 orang siswa pada siklus 1 menjadi 30 orang siswa padasiklus 2 .

Dilihat dari segi aspek analisis penilaian, setelah tindakan pembelajaran siklus 2 diketahui aspek kelengkapan format cerpen memiliki nilai rata-rata, yakni 4,3 (86). Aspek kelengkapan unsur intrinsik memiliki nilai rata-rata sebesar 3,5 (70). Aspek komposisi/struktur cerpen memiliki nilai rata-rata sebesar 3,9 (78). Aspek bahasa cerpen memiliki nilai rata-rata sebesar 4,1 (82).

Dari gambaran aspek penilaian di atas, aspek kelengkapan format cerpen memiliki nilai rata-rata tertinggi dan aspek kelengkapan unsur intrinsik memiliki nilai rata-rata terendah, serta aspek bahasa cerpen tidak mengalami peningkatan. Semua aspek penilaian memiliki nilai rata-rata di atas standar KKM. Dengan demikian dapat dikatakan bahwa semua siswa mampu memahami aspek format kelengkapan cerpen, aspek bahasa cerpen, komposisi/struktur cerpen, dan kelengkapan unsur intrinsik cerpen. Dengan demikian, proses pembelajaran menulis cerpen melalui pendekatan kontekstual berlangsung dengan baik dan lancar sesuai dengan perencanaan pembelajaran.

Indikator keberhasilan tindakan pembelajaran menulis cerpen melalui pendekatan kontekstul pada siklus 2 adalah (1) sebesar 50\% (21siswa) dinyatakan lulus atau nilainya di atas nilai KKM (70), (2) rata-rata nilai meningkat menjadi 3,5, (3) kemampuan siswa dalam menulis cepen minimal berada pada kategori "tinggi".

Jika hasil pembelajaran menulis cerpen seperti telah dijelaskan di atas dibandingkan dengan kriteria keberhasilan tindakan, dapat diketahui bahwa: (1) pencapaian nilai di atas KKM atau tingkat kelulusan siswa melampaui target keberhasilan yang ingin dicapai, yakni sebanyak 41 siswa dinyatakan lulus atau belum lulus atau nilainya di bawah nilai KKM, (2) rata-rata nilai yang didapat melampaui target keberhasilan yang diharapkan, yakni 3,5 (70), (3) kategorisasi kemampuan menulis cerpen sesuai dengan dari target keberhasilan yang diharapkan, yaitu "tinggi”. Sekalipun pada siklus 2 tidak mengalamai perubahan kategorisasi kemampuan menulis cerpen, jumlah siswa yang dinyatakan lulus atau nilainya di atas KKM mengalami peningkatan,

Berdasarkan pertimbangan tersebut di atas maka peneliti memutuskan untuk melanjutkan ke siklus selanjutnya, yakni siklus 3 dengan mlakukan pendalaman materi unsur intrinsik cerpen. Siklus 3 ini dilaksanakan untuk mengecek konsistensi peningkatan proses dan hasil kemampuan menulis cerpen melalui pendekatan kontekstual.

Pelaksanaan siklus 3 difokuskan pada permasalahan atau kekurangan yang ada berdasarkan hasil refleksi pada pelaksanaan siklus 2. Pelaksanaan siklus 3 terdiri dari 2 kali pertemuan. Materi yang diajarkan sifatnya hanya pengulangan dan penguatan dari materi yang pernah diberikan. Untuk mengetahui materi yang belum dipahami oleh siswa, guru mengadakan review dan penjelasan hasil tes menulis cerpen dan segala permasalahan yang ada sebagai bahan refleksi bersama.

Kegiatan pembelajaran difokuskan pada tipe pembelajar yang lamban dalam memahami materi (slow learner).Guru menerapkan metode mind mapping dalam penguasaan materi pembelajaran dan sistem tutor sebaya. Pelaksanaan siklus 3 diakhiri dengan tes menulis cerpen pada pertemuan kedua. Tema yang diangkat adalah pengalaman hidup para siswa sendiri.Para siswa mengedit, merevisi, dan mereview bersama-sama tulisan cerpen yang telah dibuat.

Pada tahap pengamatan siklus 3 ini, peneliti berperan sebagai guru sedangkan kolaborator berperan sebagai pengamat. Peneliti dan kolaborator juga bekerja sama untuk mengamati siswa. Dari hasil pengamatan dapat direfleksikan bahwa cara mengajar guru semakin baik. 
Kemampuan siswa dalam menulis cerpen semakin meningkat dengan tingkat kelulusan $100 \%$. Semua kendala yang dijumpai dalam proses pembelajaran menulis cerpen melalui pendekatan kontekstual dapat diatasi. Tipe pembelajar yang lamban (slow learner) dapat mengikuti dan memahami materi pembelajaran dengan baik.

Setelah tindakan pembelajaran siklus 3, rata-rata kemampuan menulis cerpen siswa sebesar 4,0 (80). Semua siswa memiliki nilai di atas KKM. Karena semua siswa memiliki nilai standar di atas KKM atau dengan kata lainlulus $100 \%$. Jika dibandingkan dengan siklus 2, tingkat kelulusan pada siklus 3 mencapai $100 \%$.Sekalipun dinyatakan lulus $100 \%$, ada 9 siswa yang mengalami penurunan nilai pada siklus 3 ini.Mereka adalah FIL, GRD, PA, REY, ABR, EMN, MRC, MRV, STV.Siswa EMN nilainya terus mengalami penurunan mulai dari siklus 2 dan siklus 3.Siswa yang nilainya tetap pada siklus 3 ini ada 3 siswa, yakni STB, CIS, GIO.

Selanjutnya, peneliti akan menjelaskan kategoriasi kemampuan menulis cerita pendek siswa kelas VII salah satu SMP swasta di Jakarta Tahun Ajaran 2014-2015. Setelah tindakan pembelajaran siklus 3 secara umum kemampuan menulis cerpen siswa berada pada kategori "sangat tinggi". Hal tersebut dibuktikan dengan data yang menunjukkan 25 siswa $(59,5 \%)$ berada pada kategori "sangat tinggi". Sebanyak 16 siswa (38,1\%)tergolong memiliki kemampuan menulis cerpen yang "tinggi". Sisanya, hanya seorang $\operatorname{siswa}(2,38 \%)$ saja yang berada dalam kategori "sedang".

Jika dibandingkan dengan siklus sebelumnya, kategori kemampuan menulis cerpen "sangat tinggi" mengalami peningkatan.Kategori kemampuan menulis cerpen "tinggi" mengalami penurunan jika dibandingkan dengan siklus 2. Sama halnya dengan kategori kemampuan menulis cerpen "tinggi", kategori kemampuan menulis cerpen "sedang" dan "rendah" juga mengalami penurunan.

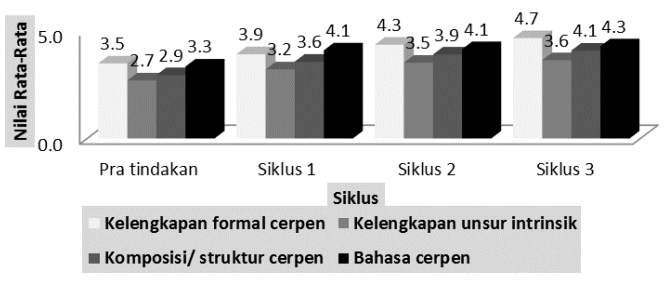

Diagram 2.Analisis Aspek Penilaian Kemampuan Menulis Cerpen Siswa Kelas VII salah satu SMP swasta di Jakarta Tahun Ajaran 2014-2015Pra Tindakan, Siklus 1, Siklus 2, dan Siklus 3

Dilihat dari analisis aspek penilaian pada diagram di atas, setelah tindakan pembelajaran siklus 3 diketahui aspek kelengkapan format cerpen memiliki nilai rata-rata, yakni 4,7 (94). Aspek kelengkapan unsur intrinsik memiliki nilai rata-rata sebesar 3,6 (72). Aspek komposisi/struktur cerpen memiliki nilai rata-rata sebesar 4,1 (82). Aspek bahasa cerpen memiliki nilai rata-rata sebesar 4,3 (86). Dari gambaran aspek penilaian di atas, aspek kelengkapan format cerpen memiliki nilai rata-rata tertinggi dan aspek kelengkapan unsur intrinsik memiliki nilai rata-rata terendah. Semua aspek penilaian memiliki nilai rata-rata di atas standar KKM. Dengan demikian dapat dikatakan bahwa semua siswa mampu memahami aspek format kelengkapan cerpen, aspek bahasa cerpen, komposisi/struktur cerpen, dan kelengkapan unsur intrinsik cerpen.

Indikator keberhasilan tindakan pembelajaran menulis cerpen melalui pendekatan kontekstul pada siklus 3 adalah (1) sebesar $100 \%$ (42siswa) dinyatakan lulus atau nilainya di atas nilai KKM (70), (2) rata-rata nilai meningkat menjadi 4, (3) kemampuan siswa dalam menulis cepen minimal berada pada kategori " sangat tinggi”.

Jika hasil pembelajaran menulis cerpen seperti telah dijelaskan di atas dibandingkan dengan kriteria keberhasilan tindakan, dapat diketahui bahwa: (1) pencapaian nilai di atas KKM atau tingkat kelulusan siswa sesuai dengan target keberhasilan yang ingin dicapai, yakni sebanyak 42 siswa (100\%) dinyatakan lulus atau nilainya di atas nilai KKM, (2) rata-rata nilai yang didapat sesuai dengan target keberhasilan yang diharapkan, yakni 4,0 (80), (3) kategorisasi kemampuan menulis cerpen sesuai dengan target keberhasilan yang diharapkan, yaitu "sangat tinggi". Berdasarkan pertimbangan tersebut di atas, peneliti memutuskan untuk menghentikan tindakan pembelajaran hanya sampai pada siklus 3 ini saja. Tujuan pembelajaran menulis cerpen melalui pendekatan kontekstual telah tercapai.

Peningkatan kemampuan menulis cerpen melalui pendekatan kontektual dipengaruhi oleh faktor keberhasilan intervensi pembelajaran: Pertama. Pembelajaran menulis cerpen melalui pendekatan kontekstual melatih siswa untuk memahami arti penting sebuah proses belajar menulis cerpen yang kompleks. Pada pembelajaran menulis cerpen melalui pendekatan kontekstual, siswa sungguh-sungguh dibimbing agar mempunyai pikiran yang kritis dan kreatif dalam menggunakan pengalaman hidupnya sebagai tema penulisan cerpen.Dari 3 kali siklus pembelajaran yang diberikan, siswa berhasil menemukan kekurangan atau kesalahannya dalam menulis dan memperbaikinya. Hal tersebut membuktikan bahwa proses belajar inkuiri siswa berjalan dengan baik. Yamin (2013:56) menjelaskan bahwa proses inkuiri merupakan salah satu komponen atau azas CTL yang penting. Inkuiri berarti proses pembelajaran didasarkan pada pencarian dan penelusuran melalui proses berpikir secara sistematis. Pengetahuan yang dipelajari menjadi milik siswa sendiri ketika pengetahuan itu dipelajari dalam kerangka konteks kehidupan nyata.

Kedua.Siswa memperoleh pengetahuan barunya dilandasi dengan nilai kerja sama dan berbagi pengetahuan dan belajar dari temannya yang kurang mampu sekalipun. Proses tersebut sesuai dengan komponen CTL, yakni masyarakat belajar. Hal tersebut sesuai dengan teori yang disampaikan oleh Sanjaya (2006:266) bahwa dalam pendekatan CTL, penerapan azas masyarakat belajar dapat dilakukan dengan menerapkan pembelajaran melalui kelompok belajar. 
Siswa yang memiliki kemampuan lebih akan membantu siswa lain yang kemampuannya kurang (tutor sebya).

Ketiga. Pada akhirnya, pengetahuan yang didapat siswa harus diaplikasikan dalam kehidupan mereka. Para siswa dapat belajar menemukan nilai-nilai hidup melalui karakter tokoh yang disajikan dalam tulisan cerpen, cara tokoh menghadapi konflik, bahkan sudut pandang penulis dalam menyelesaikan permasalahan atau konflik dan meresapkannya di dalam kehidupannya. Penjelasan tersebut sesuai dengan prinsip CTL, yakni pembelajaran bermakna (meaningful learning) (Jhonson, 1010:67).

Di samping ada peningkatan kemampuan menulis cerpen melalui pendekatan kontekstual, pada saat pelaksanaan intervensi pembelajaran dalam penelitian ini juga mengalami kendala, yakni beberapa siswa mengalami penurunan nilai tiap siklusnya.Walaupun demikian, penurunan nilai tersebut tidak terlalu berpengaruh pada penurunan kemampuan siswa dalam menulis cerpen karena nilai siswa tetap berada di atas KKM. Kemungkinan-kemungikan alasan yang menjadi penyebab penurunan nilai tersebut: (1) siswa belum bertanggung jawab sepenuhnya dalam proses pembelajaran mandiri, (2) kemampuan reflektif siswa belum maksimal sehingga kesalahan yang sama terjadi berulang-ulang, dan (3) kurangnya perhatian terhadap kebutuhan belajar tipe pembelajar yang lamban dalam memahami materi 'slow learner'.

\section{PENUTUP}

\section{Simpulan}

Berdasarkan pembahasan hasil penelitian di atas, dapat disimpulkan bahwa penerapan pendekatan kontekstual dinilai efektif dalam pembelajaran menulis cerita pendek. Hal tersebut ditunjukkan dengan adanya peningkatan kemampuan menulis cerita pendek pada siswa kelas VII salah satu SMP swasta di Jakarta meliputi proses dan hasil pembelajaran.

\section{Saran}

Maka dari itu, guru diharapkan semakin kreatif dan inovatif dalammemberikanpembelajaran menulis cerpen melalui pendekatan kontekstual.Guru diharapkan mampu mengembangkan metode, strategi, dan teknik yang mendukung terciptanya pembelajaran kontekstual yang aktif, kondusif, dan menyenangkan. Guru hendaknya memfasilitasi cara belajar siswa secara mandiri dengan mengedepankan nilai tanggung jawab sehingga siswa senantiasa bertanggung jawab terhadap dirinya pada saat belajar.

Guru perlu mengembangkan metode reflektif dalam pembelajaran menulis cerpen melalui pendekatan kontekstual. Metode reflektif merupakan kesadaran untuk merenungkan kembali perasaan, pikiran, dan tindakan yang sudah dilakukan sebagai bentuk perbaikan diri ke arah yang lebih baik. Dengan demikian, para siswa akan sungguh-sungguh memaknai proses belajarnya.

Guru perlu menganalisis kebutuhan siswa dari berbagai sudut pandang sebelum memulai pembelajaran. Hal itu dilakukan sebagai upaya guru untuk mengidentifikasi faktor-faktor pendukung dan penghambat proses pembelajaran guna memilih dan menentukan media yang tepat dan relevan mencapai tujuan pembelajaran dan mengarah pada peningkatan mutu pendidikan. Analisis kebutuhan ditujukan untuk menentukan keperluan atau harapan siswa.

\section{DAFTAR PUSTAKA}

Abrams, M.H. 1999. A Glossary of Literary Terms, Seventh Edition. USA: Thomson Learning.

Aksan, Hermawan. 2011. Proses Kreatif Menulis Cerpen. Bandung: Nuansa.

Burroway, Janet, Elizabeth Stuckey-French, \& Ned stuckey-Frenc. 2011. Writing Fiction, A Guide To Narrative Craft. United States: Pearson.

Carroll, Joyce Armstrong and Edward E. Wilson. 1993. Acts of Teaching, How to Teach Writing: A Text, A Reader, A Narrative. USA: Teachers Idea Press.

Colibabam, Stefan. "The Nature of The Short Story: Attempts At Definition”. Synergy. Vol. 6 (2): hlm. 220.

Disher, Garry. 2011. Writing Fiction, An Introduction To The Craft. Australia: Allen\&Unwin.

Harefa, Andrias. 2007. Mengukir Kata, Menata Kalimat. Yogyakarta: Gradien Books.

Hopkins, David. 1993. A Teacher's Guide to Classroom Research. Philadelphia: Open University Press.

Ideris, Haderi. 2013. Pintar Menulis Cerpen: Cara Jitu Mendobrak Pintu Kesulitan Menulis. Banjarmasin: Dreammedia.

Jhonson, Elaine B. 2010. CTL (Contextual Teaching and Learning): Menjadikan Kegiatan Belaja-Mengajar Mengasyikan dan Bermakna. Bandung: Kaifa Learning.

Keraf, Gorys. 2006. Diksi dan Gaya Bahasa. Jakarta: PT Gramedia Putaka Utama.

Lucke Margaret. 1999. Schaum's Quick Guide to Writing Great Short Stories. New York: McGraw Hill.

McCrimmon, James M. 1984. Writing with a Purpose. USA: Houghton Mifflin Company.

McMahan, Elizabeth, Susan X. Day, dan Robert Funk. 1995. Literature and Writing Process. New Jersey: Prentice-Hall, Inc.

Murray, Rowenna \& Sarah Moore. 2009. The Handbook of Academic Writing, A Fresh Approach. New York: Mc-Graw Hill.

Nurgiyantoro, Burhan. 2013. Teori Pengkajian Fiksi. Yogyakarta: Gajah Mada University Press. 
Philbin \& Presley. 1989. Technical Writing, Method, Application \& Management. USA: Delmar Publishers.

Richards, Jack C. dan Willy A. Renandya. 2002. Methodology in Language Teaching,An Anthology of Current Practice. USA: Cambridge University Press.

Sanjaya, Wina. 2006. Strategi Pembelajaran Berorientasi Standar Proses Pendidikan. Jakarta: Kencana.

Zainurrahman. 2011 Menulis: Dari Teori Hingga Praktik (Penawar Racun Plagiarimse). Bandung: Alfabeta.

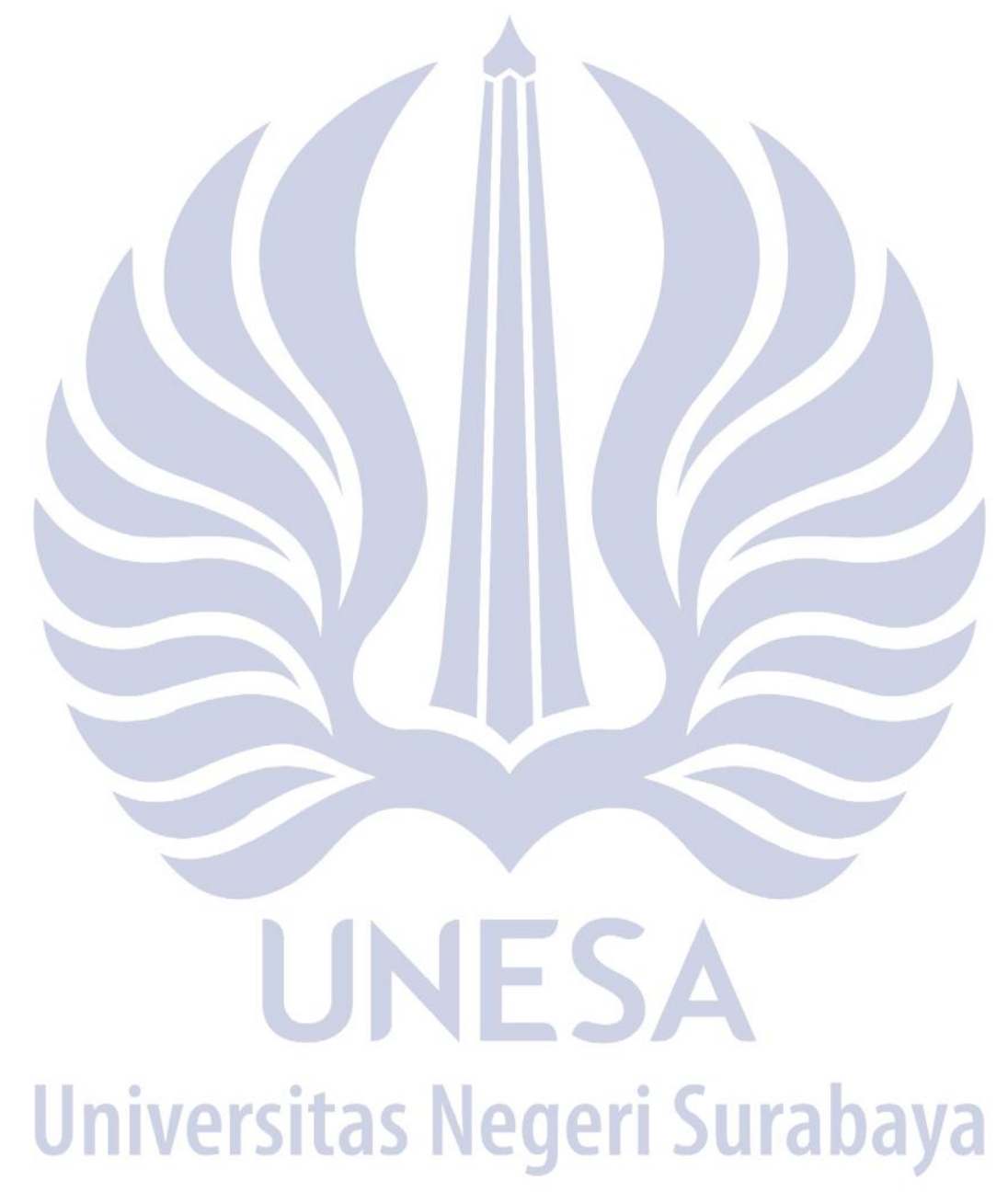

